\title{
IMMUNOLOGICAL COSTS OF MATING TO MALE SAGEBRUSH CRICKETS
}

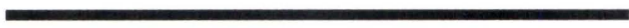

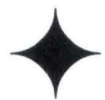 \\ JOSEPH C. LEMAN $\downarrow$ CARIE B. WEDDLE $\downarrow$ GEOFF D. OWER $\uparrow$ SCOTT K. SAKALUK \\ BEHAVIOR, ECOLOGY, EVOLUTION AND SYSTEMATICS SECTION \\ DEPARTMENT OF BIOLOGICAL SCIENCES $\uparrow$ ILLINOIS STATE UNIVERSITY $\downarrow$ NORMAL
}

\begin{abstract}
$\uparrow \quad$ ABSTRACT
Male sagebrush crickets, Cyphoderris strepitans, offer an unusual nuptial food gift to females during mating: females chew on the ends of the males' fleshy hind wings and ingest hemolymph seeping from the wounds they inflict. Previous research has shown that once a male has mated, his probability of obtaining an additional copulation is reduced relative to that of a virgin male seeking to secure his first mating, a pattern known as the virgin-male mating advantage. One hypothesis that may explain this phenomenon is that mated males experience an energetically costly immune response via their wounds and therefore may be unable to sustain the costly acoustical signaling needed to attract additional females. To distinguish between the effects of mounting a costly immune response and the costs of producing a spermatophore, we mimicked a nonvirgin mating status by injecting virgin males with bacterial lipopolysaccharides, a non-living elicitor of several immune pathways. After they had been treated, males were released in the field and recaptured over the course of the breeding season to monitor their mating success. Contrary to our prediction, LPS injected males did not take longer to secure matings than sham-injected virgin males. However, a companion study revealed that immunochallenged virgin males spent significantly less time calling (as assayed using time-lapse video photography) than shamcontrol virgin males. This confirms work in other cricket species showing a decline in mating effort following an immune challenge.
\end{abstract}

\section{$\downarrow \quad$ INTRODCTION}

The sagebrush cricket, Cyphoderris strepitans, is one of only seven extant species of a relatively unknown orthopteran family, the hump-winged grigs (Haglidae) (Kumala et al. 2005). C. strepitans occurs exclusively in highaltitude sagebrush meadows in mountainous areas of Colorado and Wyoming (Morris and Gwynne 1978). Mating occurs in the late spring after the snow melts. Males climb into sagebrush or lodegepole pine shortly after sunset to secure a perch, from where they emit acoustical signals that function to attract females (Snedden and Irazuzta 1994), and which appear to be the primary means of pair formation (Snedden and Sakaluk 1992). Copulation is initiated when a female climbs onto the dorsum of the male, at which time he attempts to transfer a spermatophore, a small gelatinous packet containing sperm. During copulation, the female feeds on the male's fleshy hind wings and the hemolymph that oozes from the wounds she inflicts. After the spermatophore has been transferred, the male actively pulls away from the female, terminating wing feeding (Eggert and Sakaluk 1994).

Virgin males secure more matings than their relative abundance in the wing tissue and hemolymph, they must also produce in the population would predict, a population wide pattern that has been described as the "virginmale mating advantage" (Morris et al. 1989; Sakaluk and Ivy 1999; Snedden 1996). Mating appears to be costly to males: not only do they lose a significant portion of their hind wing 
tissue and hemolymph, they must also produce another spermatophore if they are to mate again. Previous work has shown that non-virgin male calling time is reduced relative to virgin males (Sakaluk et al. 1987; Sakaluk and Snedden 1990).

One possible mechanism underlying the reduction in non-virgin male calling time is that a male's immune system is activated when his integument is breached via wing-feeding by females at mating, and that resources allocated to the ensuing immune response comes at the expense of the resources that would otherwise be devoted to acoustic signaling. While a number of studies have shown tradeoffs between investment in immune responses and the expression of secondary sexual characteristics (Sheldon and Verhulst 1996; Faivre et al. 2003), the present study would be the first to show, to the best of our knowledge, that mating itself can result in an immune response that constrains a male's future mating success. Of particular relevance to our study, recent work has shown that experimentally-induced immune responses in field crickets result in a reduction in male calling time (Jacot et al. 2004).

The objective of the present study was to determine the effects of an induced immune response on male sagebrush cricket mating success in a mark-recapture study. If the immune response resulting from female wing feeding during copulation is responsible for the decline in non-virgin male mating success, then virgin males subjected to a similar immunological challenge should exhibit a similar decline in the incidence of matings. This should occur because male calling time should be reduced via the mounting of an energetically costly immune response.

\section{$\rightarrow \quad$ METHODS}

A mark-recapture study was conducted from May 21 to June 15, 2006 in Grand Teton National Park, Wyoming. A rectangular study plot of approximately $120 \mathrm{~m} \mathrm{X} 80 \mathrm{~m}$ was established in sagebrush meadow habitat adjacent to the Snake River at Deadman's Bar. During the early portion of the breeding season, we attempted to capture and mark all of the virgin males present in the study plot. Males were found at night by orienting to their calls and using head lamps to determine their exact location within a sagebrush bush. The mating status of males was determined by examining their hind wings for the wounds inflicted by females; only virgin males, as evidenced by intact wings, were used in experimental treatments. Each virgin male was placed in a collecting vial, numbered to correspond with a surveyor's flag placed at the capture location, and transported to the University of WyomingNational Park Service Research Center, approximately $30 \mathrm{~km}$ away, for processing.

Captured males were randomly assigned to one of two treatments: 1) males injected with $50 \mu \mathrm{g}$ of bacterial lipopolysaccharides (LPS) in $10 \mu \mathrm{l}$ of Grace's insect medium, and 2) sham-control males injected with $10 \mu \mathrm{l}$ of Grace's insect Medium. LPS was chosen as it is the non-living, nonpathogenic portion of a gram negative bacterial cell wall which represents a common insect pathogen, Serratia marcesens (Adamo et al. 2001). Injections were administered ventrally between the third and fourth sternites using a 10 $\mu$ l Hamilton syringe (Jacot et al 2004). Each male was marked individually with a numbered plastic tag secured to the pronotum with cyanoacrylic glue, and his femora painted with fluorescent model paint (Testors ${ }^{\circledR}$ ) of a unique color that designated the treatment to which he had been assigned. Portable ultraviolet lanterns, the illumination of which caused the paint to fluoresce in the dark, were used to facilitate the capture of experimental individuals at night. The following evening at sunset, marked males were returned to their respective points of capture. We marked and released a total of 86 males (43 sham-control, 43 LPS-injected) over the course of five nights (May 21-May 25).

After experimental males had been released, males were recaptured and examined for evidence of mating activity regularly over the course of the breeding season, usually every second night, weather permitting. Mating activity was inferred by loss of hind wing material in all treatments. Wing wounds were classified as "fresh" (visibly wet wounds with no discoloration indicating that the male had mated on the night of capture) or "old" (dry, darkened wounds indicating that the male had mated at least one night previous to the night of capture).

A time-lapse video study took place concurrently with the field study in which we determined the effects of an induced immune 
response on male calling effort. Two groups of virgin males were established in the same way as in the mark-recapture study, except that these males were collected from another population at Pacific Creek, approximately $20 \mathrm{~km}$ away from Dead Man's Bar. Each night of the study, males from each of the two treatments were paired with females at about $2000 \mathrm{~h}$, and their mating activity monitored over a 5-hour period using time-lapse video photography. Nighttime recording was facilitated by the illumination provided by a $25-\mathrm{W}$ red light bulb. Experimental pairs were confined in a Plexiglas viewing chamber $(17 \times 12 \times 3.5 \mathrm{~cm})$, divided into four equal compartments to prevent contact between crickets of different pairs, each of which contained a short stick to serve as a calling perch. Upon review of video recordings, we determined the time spent calling by each male during the trial, measured as the number of 5min intervals in which stridulation occurred (one-zero sampling; Altmann 1974)

All data were analyzed using SAS (SAS Institute, 2004).

\section{RESULTS}

Survival of experimental males was determined as the number of nights from the time a male was first captured to the night on which a male was last recaptured. We excluded from this calculation males that were never recovered following their initial release (see above) because these males may have lost their tags or immediately left the study area owing to the trauma of release. Males that were still alive on the last night of the study were treated as 'censored' observations. To compare survival across treatments, we employed failure time analysis (Fox 1993). Failure-time analysis accommodates censored data, observations in which an event such as a male's death or mating may not have occurred by the end of the study, as was the case here. Omission of such data, as is frequently done in behavioral studies, may lead to a serious bias in comparisons across treatments (Fox, 1993). There was no difference in male survival across treatments (Log-Rank $\chi^{2}$ $=1.51, P=0.22$ ).

Time to mating was determined as the number of nights from the time a male was first released until he was captured as a non-virgin. Non-virgin males bearing fresh-wing wounds were assumed to have mated on the night they were captured. Non-virgin males bearing oldwing wounds were assumed to have mated at least one night previous to their capture or, if they had not been captured in the previous census, we recorded the night of mating as the mid-point of the earliest time they could have mated and the latest time they could have mated. Males that had still not mated by the time of their last capture were treated as 'censored' observations. We used failure time analysis to compare time to mating of sham control males with that of LPS injected males. LPS-injected males obtained matings at a lower rate than control males, but the difference was not quite statistically significant $\left(\log -\operatorname{Rank} \chi^{2}=2.64, p=\right.$ 0.104 , Figure 1). We believe that this was due to a high percentage of censored observations (males that failed to secure a copulation over the duration of the study), because slightly more than half of the male population had already mated by the time we initiated the study because of an unseasonably warm early spring (Table 1).

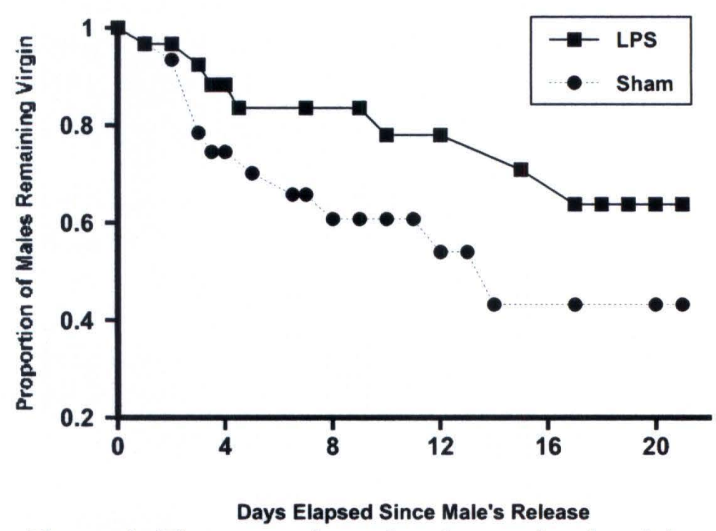

Figure 1. The proportion of male sagebrush crickets remaining unmated as a function of time elapsed since their initial release. LPS-males took longer to secure mating than control males, but the difference was not statistically significant (Log-Rank $\chi^{2}=2.64, p=$ 0.104).

\begin{tabular}{|l|c|c|c|c|}
\hline Treatment & $N$ & Mated & Unmated & \% Censored \\
\hline LPS injected & 30 & 7 & 23 & 76.7 \\
\hline Sham control & 31 & 12 & 19 & 61.3 \\
\hline
\end{tabular}

Table 1. Number of males that mated and number of males that failed to mate by the end of the study (censored observations).

Calling data from the video study were analyzed using a repeated-measures ANOVA, with time (first night or second night of recording) entered as the repeated factor and treatment (LPS-injected or sham-control) entered as the other main effect. Control males called 
significantly more than LPS-injected males $(F=$ 5.08, $P=0.030)$. There was no significant difference in calling time across nights $(F=1.99$, $P=0.17)$, and nor was there a significant time* treatment interaction $(F=0.32, P=0.57$; Figure 2)

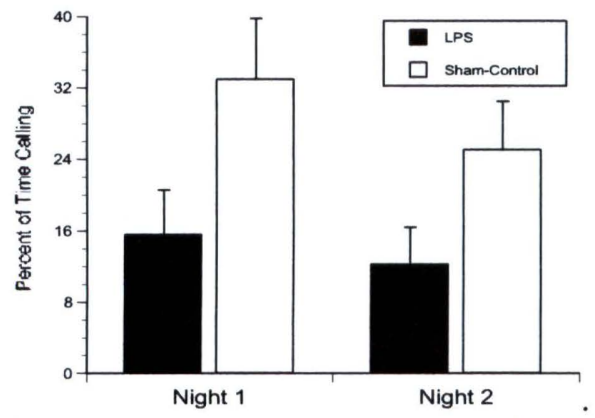

Figure 2. Mean percent of time spent calling ( $+\mathrm{SE})$ by LPS-injected males and sham-control males over two consecutive nights.

\section{$\downarrow$ DISCUSSION}

There was no significant difference between LPS-injected virgin males and control males, a result that is inconsistent with the hypothesis that the virgin male mating advantage occurs because males incur an energetically costly upregulation of the immune system as a result of the wing wounding they experience at mating. However, immunochallenged males spent significantly less time calling compared to control males. Because calling is vital to pair formation and hence, mating success (Snedden and Sakaluk 1992), this result provides evidence that supports the hypothesis. While a number of studies have shown tradeoffs between investment in immune responses and investment in secondary sexual characteristics (Sheldon and Verhulst 1996; Faivre et al. 2003; Jacot et al., 2004), no study has shown that mating itself can result in an immune response that compromises future mating success.

Even if LPS injected males were shown to secure fewer matings than sham injected males, more work would be necessary to understand the proximate underpinnings of this cost. Direct physiological evidence of a differential immune response of virgin males and non virgin males is required, and the specific correlates of immunocompetence remain to be identified (Adamo 2004). To that end, we will be conducting three kinds of laboratory-based immunoassays on field-collected virgin and nonvirgin male $C$. strepitans in $2006: 1$ ) an encapsulation rate assay, 2) a phenoloxidase activity assay and 2) a lyoszyme-like activity assay.

\section{ACKNOWLEDGEMENTS}

This research was conducted in Grand Teton National Park under the auspices of a Scientific Research and Collecting Permit (GRTE-2006-SCI-0030) issued by the National Park Service. We thank Hank Harlow and Rich Viola of the UW-NPS Research Center for logistic support. This research was supported by grants from Illinois State University and the National Science Foundation (IBN-0126820) to S.K.S., and grants from the Beta Lambda Chapter of the Phi Sigma Biological Honors Society and the Graduate School at Illinois State University to JCL.

\section{$\downarrow$ Literature Cited}

Adamo, S.A. 2004. How should behavioral ecologists interpret measures of immunity? Animal Behavior 68:14431449.

Altmann, J. 1974. Observational study of behavior: sampling methods. Behaviour 49:227-267.

Eggert, A-K, S.K Sakaluk. 1994. Sexual cannibalism and its relation to male mating success in sagebrush crickets, Cyphoderris strepitans (Orthoptera: Haglidae). Animal Behavior. 47:11711177.

Faivre, B., A. Gregoire, M. Preault, F. Cezilly, G. Sorci. 2003. Immune activation rapidly mirrored in a secondary sexual trait. Science 300:103.

Fox, G.A. 1993. Failure-time analysis: emergence, flowering, survivorship and other waiting times. In: Design and analysis of ecological experiments, (Scheiner SM, Gurevitch J, eds). New York: Chapman \& Hall. p. 253-289. 
Jacot, A., H. Scheuber, M.W.G. Brinkhof. 2004. Costs of an induced immune response on sexual display and longevity in field crickets. Evolution 58:2280-2286.

Kumala, M., D.A. McLennan, D.R. Brooks, A.C. Mason. 2005. Phylogenetic relationships within hump-winged grigs, Cyphoderris (Insecta, Orthoptera, Tettigonioidea, Haglidae). Canadian Journal of Zoology 83:1003-1011.

Morris, G.K., D.T Gwynne. 1978. Geographical distribution and biological observations of Cyphoderris (Orthoptera: Haglidae) with a description of a new species. Psyche 85: 147-167.

Morris, G.K., D.T. Gwynne, D.E. Klimas, S.K. Sakaluk. 1989. Virgin male mating advantage in a primitive acoustic insect (Orthoptera: Haglidae). Journal of Insect Behavior 2:173-185.

Sakaluk, S.K., T.M. Ivy. 1999. Virgin-male mating advantage in sagebrush crickets: differential male competitiveness or non-independent female mate choice? Behaviour 136:1335-1346.

Sakaluk, S.K., W.A. Snedden. 1990. Nightly calling durations of male sagebrush crickets, Cyphoderris strepitans: size, mating and seasonal effects. Oikos 57:153-160.
Sakaluk, S.K., G.K. Morris, W.A. Snedden. 1987. Mating and its effect on acoustic signalling behavior in a primitive orthopteran, Cyphoderris strepitans (Haglidae): the cost of feeding females. Behavioral Ecology \& Sociobiology 21:173-178. SAS Institute Inc. 2004. SAS OnlineDoc ${ }^{\circledR}$ 9.1.3. SAS Institute Inc: Cary, NC.

Sheldon, B.C., S. Verhulst. 1996. Ecological immunology: costly parasite defences and trade-offs in evolutionary ecology. Trends in Ecological Evolution. 11:317321.

Snedden, W.A. 1996. Lifetime mating success in male sagebrush crickets: sexual selection constrained by a virgin male mating advantage. Animal Behavior. 51:1119-1125.

Snedden, W.A., S. Irazuzta. 1994. Attraction of female sagebrush crickets to male song: the importance of field bioassays. Journal Insect Behavior. 7:233-236.

Snedden, W.A., S.K. Sakaluk. 1992. Acoustical signalling and its relation to male mating success in sagebrush crickets. Animal Behavior. 44:633-639. 